\title{
Turkey's Involvement in the Syrian Conflict from a Defense Management Perspective
}

\author{
Muhammad Zulham1, Hendra Maujana Saragih', \\ Suyono Thamrin ${ }^{1}$, Tatar Bonar Silitonga ${ }^{1}$ \\ ${ }^{1}$ Indonesia Defense University, Bogor, Indonesia, \\ 2Universitas Nasional, Jakarta, Indonesia \\ mzulham712@gmail.com, hendramaujana@gmail.com (correspondence), \\ suyono.thamrin@idu.ac.id, tatarbonar@idu.ac.id
}

\begin{abstract}
This article will discuss Turkey's interests in resolving the Syrian conflict from the perspective of defense management. The Syrian conflict that demanded the resignation of President Bashar al-Assad made all countries in the world want to participate in conflict resolution. Turkey is no exception. Turkey is one of Syria's close neighbors and is interested in it. National defense and economic interests are the main factors of Turkey in the Syrian conflict. The deployment of strategic depth of foreign policy has become the benchmark for conflict resolution. National defense management is a new science for realizing national interests, and its strategic environment must be reviewed. Therefore, as one of the important actors in the Middle East, Turkey has the aforementioned policies in realizing its national interests. This article uses qualitative methods in the conclusion. This article uses assumptions from realism to constructivism, national interest theory of national defense theory and national defense management theory. The conclusion of this article is that defense management (Assad's call for resignation) is based on preventing Syrian refugees from going to Turkey. A large number of refugees from Syria may undermine Turkey's security and stability. The aim is to maintain Turkey's social and economic stability, which may be shaken by the existence of these refugee groups. Achieving this goal by providing support and weapon assistance to the Syrian rebels is considered a form of preventing the spread of the Syrian conflict. In addition, Turkey also hopes to join NATO.
\end{abstract}

Keywords: Turkey, Strategic Depth, Defense Management, Defense, Economy 


\section{Introduction}

The Syrian conflict began with protests by the Syrian people, demanding democratization in Syria. The operation was triggered by the Bashar al-Assad government, which is considered an authoritarian regime. The Bashar al-Assad government responded to these actions with repressive actions, which resulted in the deaths of hundreds of demonstrators. Subsequently, this incident became the focus of attention of the international community, especially the violation of human rights. Many international agencies have urged the Syrian government to stop its repressive measures against demonstrators. However, the Syrian government ignored this request and triggered a serious reaction from the international community. (BBC Indonesia 2013).

The reaction seems to be one of them. Turkish Prime Minister Recep Tayyip Erdogan expressed disappointment in opposition to teresebut on April 20,2011. Erdogan said in a statement that the actions taken by the Bashar al-Assad regime against the demonstrators violated the values of democracy and that firing at the protesters is considered an inhumane move, so it is necessary in Syria Reshape democracy (BBC News 2016).

On August 9, 2011, the Turkish government demanded that the Syrian government under the Bashar al-Assad regime stop shooting and arrests of demonstrators, and requested that the government system be changed to be more democratic. However, Turkey's request did not receive a response from the Syrian government under the leadership of Bashar al-Assad on the grounds that the incident was the internal affair of the Syrian government, so other parties are not expected to interfere in the internal affairs. Syrian government affairs (Aljazeera 2011).

The refusal aroused strong opposition from the Turkish government. Turkish Prime Minister Recep Tayyip Erdoğan condemned the action and called for international action against the Syrian government's actions deemed human rights violations. Sanctions, and Erdogan believes that Syria has heeded the warning. Officials from the Turkish government and even the Syrian government said they will continue to take these actions because this is an internal affair of the 
Syrian government. In this regard, if the Turkish government listened to the Turkish government's request for repressive measures against the demons related to it, it also expressed a threat of embargo against the Syrian government. According to this issue, the relationship between Turkey and Syria has entered the initial stage of separation. Since 2009, the relationship between Turkey and Syria has experienced harmony (Akbar, 2011).

The victory of the Adalet ve Kalkinma Partisi (AKP) also opened a new page in the relations between Turkey and Syria in the 2002 election. This is due to the secular Kemalist ideology of Cumhuriyet Halk Partisi (CHP) before 2002, and its foreign policy China paid great attention to the policies of Western countries and was then replaced by the Islamic ideology of AKP. One form of the AKP policy is to normalize the cooperative partnership with Islamic countries, especially Arab countries in the field of trade, and to use defense cooperation as a new form of regional power in the Middle East. When problems occur in Iraqi Kurdistan, this situation has brought closer relations between Turkey and Arab countries, especially Syria. Turkey and Syria form an alliance to support the Iraqi Kurdish state (Tezcür 2009).

In view of Turkey's geographic location and Turkey's ability to inhibit EU accession, several senior Turkish government officials, especially AKP, took regional potential as a solution. The Turkish government under the leadership of Prime Minister Receep Tayyip Erdoğan and Turkish Foreign Minister Ahmet Davutoğlu has adopted a good neighborhood policy and adopted a foreign policy doctrine called "strategic depth". Strategic depth is a multidimensional approach to foreign policy based on an understanding of history and Turkey's geostrategic position. The direction and direction of Turkey's new foreign policy has greatly changed the political map of the region. Due to the proximity of the location (Feffer), these two policies make Turkey's foreign policy more oriented towards the Middle East.

Turkey and some Arab countries, especially Syria, have also considered economic and trade factors. Turkish society has long been conducting trade activities with Syria, including the issue of smuggling goods into Syria. Earlier, the Turkish government imposed an embargo 
policy on the Kurdistan Workers' Party (PKK), which is a banned organization in Turkey and is protected by the Syrian government. After the AKP came to power in 2002, the emotional problems between Turkey and Syria have eased. Since then, some trade policies between the two countries have become more relaxed, thereby increasing the volume of trade transactions between the two countries (BBC News 2015).

On November 21, 2011, Syrian government forces attacked a bus containing Turkish pilgrims that had just returned from Saudi Arabia, and the tension between Turkey and Syria reached its peak. The attack occurred in the Homs region, the border area between Turkey and Syria (BBC News 2015).

Considering that the analysis of the strategic environment is very important, defense management is a relatively new science used to study defense subdivisions. This is because the strategic environment affects defense management (Supriyatno, 2019). Not only that, but also political, economic, social and technical conditions. In a broad context, the impact of the strategic environment on defense management is very important.

From this background, the author wants to clarify the importance of Turkey's involvement in the Syrian conflict from the perspective of defense management. According to this research, the author hopes to use the essence of defense management research to explain Turkey's interests as an Islamic State, which is the basic background of defense research. Perhaps this kind of defense research may be useful for reviewing contemporary issues of Islamic studies.

In this study, the author used a qualitative method for descriptive analysis. Qualitative research refers to the research procedure that generates descriptive data and studies and observes phenomena. According to Bogdan and Taylor, they describe the qualitative method as a research procedure that generates descriptive data in the form of human written or oral expressions and observable behaviors (Taylor 2011).

The qualitative paradigm is the process of research to understand social issues by creating a comprehensive and complex picture that is 
displayed in text, reporting detailed views obtained from information sources and conducted in the natural environment (Cresswell 2016).

When writing this scientific work, the second data, namely data collection technology, is used. The technology used is a research library obtained from various books, printed media articles, journals, documents, and Internet sites according to the topic to be discussed. Data sources, the data sources in this study come from news, pictures, photos or the results of previous policies, these data can be used as a reference for precise and accurate data (Cresswell 2016).

This research is a descriptive analysis, which aims to discover in detail the actual information describing the phenomenon, identify problems and the content applicable to related theories, so that conclusions can be drawn from the phenomenon and evaluations can be provided. This research was conducted by collecting data and then grouping them according to the discussion material. After that, find the relationship between one kind of data and another kind of data, and use theory to analyze to find answers to research questions. The result of studying the answer comes to a conclusion.

\section{Concept of National Interest}

National interest is the main concept in international relations. All countries are always involved in the process of achieving or ensuring the realization of their national interest goals. Each country's foreign policy is formulated in accordance with its national interests and is always committed to achieving its goals. This is a right generally accepted by every country to ensure its national interests. Morgenthau said that national interest means survival-protection of physical, political and cultural characteristics from other nation-states.

Hans Morgenthau's concept of "national interest" appeared for the first time in the article "Primary Position of National Interest", which was a forum by American scholars in the spring of 1949 entitled "National Interest and Moral Principles in Foreign Policy" a part of. Schulman believes that national interests first have a special analytical position in 
this article. In this article, the national interest is first of all the necessary amendments to the American legal system, moralism, and sentimental characteristics described by Morgenthau in "Scientific Man and Power Politics". Politics, and as a more effective foreign policy guide than the American tradition seems to provide (Navari 2016).

In a world where many countries compete for and oppose power, survival is their absolute and minimum requirement. "Therefore, all countries are doing what they cannot but cannot do: to protect their bodies, political and cultural identities from other countries. The concept of interest is indeed a political substance. Therefore, it is eternal and not subject to The influence of time and place. As the world is politically organized into nations, the basic element of national interest, namely survival, is the last word in world politics (Kiyonno 1969, 2-3). The basic national interest can be described as national defense, Economics, and world political interests, up to ideology.

\section{Defense Theory}

Defense Science believes that defense is a crucial factor, especially in ensuring the survival of the country. As a result, all citizens in the world are studying national defense. Therefore, national defense not only involves war, weapon systems and military affairs, but also involves a wide range of aspects. In essence, national defense science is born from the development of military science and war science in the context of military development and strategic military strategy to realize national interests (Supriyatno 2014).

Defense is one of the most important aspects of a country, so the concept of national defense management varies from country to country. Differences related to concepts usually depend on the impact of history, ideology, politics, geographical conditions, social culture, laws, national defense and security systems on the threats faced by each country.

In his book "People, Fear, and the State", Barry Buzan emphasized defense through security from various perspectives from the micro to the macro. It also discussed the social aspects of security and how people or communities build or "Protection" threats. Constructivists emphasize 
that political, military, economic, social, and environmental aspects interact with each other.

Military threats will affect all areas of the country. This raises the issue of the basic obligation of a country to protect its citizens, and it also has an adverse effect on the "level of social and personal interests" (Buzan 1991). Social security is perhaps the most interesting of the five items to consider. Although it is difficult to separate it from the political sector, the threat to society lies in the identity and balance (or lack of balance) that can be found in any country.

Facts have proved that the environmental sector is difficult to define and can be considered the most controversial of the five sectors. The ecological sector will receive more attention. Measures to overcome this problem will depend on economic security and political security, because this issue can not only be seen as a threat to a single country, but also as a global threat with far-reaching impact.

\section{Defense Management Theory}

Defense management are the development of the science of business management that is tailored to the field. Then along with the development of a strategic environment where defense science is a science that must be possessed by all citizens, it is necessary to compensate for a management in the field of defense itself. The emergence of defense management as an effort carried out by defense organizations in managing defense and dealing with problems of allocating budget and human resources, as well as solving strategic or operational problems through a comprehensive approach.

Hari Bucur Macur, Philipp Fluri, and Todor Tagarev (2009) briefly explained that there is no unified definition of defense management, but defense management includes the idea that defense organizations need to effectively implement defense policies in order to formulate appropriate plans and measures. Sustainable development and support existing defense systems and infrastructure.

Supriyatno was successful in his introduction to defense management, which defines defense management as a policy that can 
guide the government to establish advanced and powerful defense capabilities. National defense management research is closely related to the success or failure of a country to manage its national resources to prepare its national capabilities in order to win a war (Supriyatno 2014).

Based on the above explanation, the main goal of implementing the concept of national defense management in a country is to manage the potential of all national armed forces to achieve a strong national defense system. Essentially, defense management uses management functions such as planning, organization, execution, control, and evaluation (in this case, we will condense to POACE). The defense and military organizations perform five functions in each of their strategic, operational and tactical activities (Supriyatno 2014).

Considering that the analysis of the strategic environment is very important, defense management is a relatively new science used to study defense subdivisions. This is because the strategic environment affects defense management (Supriyatno, 2019). Not only that, but also political, economic, social and technical conditions. In a broad context, the impact of the strategic environment on defense management is very important.

Changes have greatly affected the national defense management of a country. These changes review a very dynamic strategic environment. In this case, decision makers will perform management functions in a dynamic situation based on the strategic environment. In this case, the strategic environment referred to by the author is an international political environment that can affect a country's domestic or foreign policy.

\section{Discussion}

Turkey has many interests in Syria, some of which are in conflict. The most important goal is to restore border security. More specifically, this includes preventing the spread of violence to Turkey and preventing the conflict from affecting Turkey's Kurdish issue itself. In addition, Ankara is seeking to restore the role that Syria has begun to play in trade with the Middle East and turn the crisis into an opportunity to expand Turkey's opportunities as a regional power. The Turkish government also faces the fear of the 1990 Gulf War. In the first Gulf War in 1990, Turkey 
faced the threat of a large influx of refugees from Iraq into the border area between Turkey and Iraq. With this experience, the Turkish government especially avoided a new round of humanitarian crisis and regional turmoil. (Zurcher 2003).

Turkey's main interest in Syria lies in the defense sector. That is to avoid a large and possibly permanent influx of refugees from Syria. Although it has opened its borders to 300,000 Syrians fleeing violence (and this number is increasing every day), Ankara wants to see them deported as soon as possible. Its purpose is to alleviate the economic tensions of housing, supporting and caring for so many refugees, and to avoid assimilating them with the Turkish population, because the tensions between Syrian groups may trigger social conflicts in the Turkish population (Shukran 2019).

The issue of immigrants seeking asylum is one of the issues that may affect Turkey's national resilience, in addition to the Turkish government's concern and the threat of the conflict spreading to Turkish territory. Although Alevi, an alien Turk who lives in one-sixth of the population, has little in common with Syria's Alawis or Nusayris, Turkish politicians tend to combine the two, which intentionally or unintentionally exacerbated the minority Alevi's Sunnis are in the majority. Moreover, Islamic extremists trying to reach Syria use Turkish territory. Just like Jabhat l-Nusra, it is easy for these groups to establish a foothold in Turkey itself, which can quickly create tensions, especially if these groups seek the tension that they often do, use their religious ideas in Turkey and oppose the Turkish authorities.

Turkey tried to prevent the collapse of the Pungurangan central government and led to the Kurds who established power in northern Iraq like Iraq, because the power vacuum in northern Iraq led to the establishment of a country. Such a thing would pose a dual threat to Turkey: First, it would provide a larger base for the PKK, which might force Ankara to intervene in military affairs to prevent the group from targeting Turkey from bases crossing the border. Second, the establishment of a self-controlled Kurdish entity is the firepower of Kurdish nationalism in Turkey itself. Therefore, Turkey's important goal is to prevent Syria from achieving Kurdish autonomy. The opening of the 
Turkish economy to the Arab world has always been an integral part of this economic success, and Syria's penetration of the Arab market in Turkey is crucial.

Syria is Ankara's only land corridor through Jordan, Saudi Arabia, Egypt and other regions, which has strengthened the strategic appeal of closer bilateral relations between the two countries over the past five years. In the past ten years, the share of Arab exports in Arab countries rose from $9 \%$ to $21 \%$. On the eve of the uprising, exports to Syria surged from US $\$ 250$ million in 2002 to US $\$ 1.8$ billion. However, the current turmoil has forced Turkey to divert trade through other channels, including the Kurdish regional government. Since 2010, exports to Syria have fallen by more than $70 \%$. Turkey's regional aspirations also foresee another role for Syria in the past decade: Turkish customers. Erdogan tried to transform the Syrian government led by Assad into a junior partner in alliance with Turkey, led by and influenced by the AKP. Therefore, a key element of Turkey's current interests in Syria is to replace Assad with a government that responds to Turkey's problems and interests. It is best to seek Turkey's advice and support and support Turkey's aspirations to regional powers. (BBC News 2015).

Turkey's role will be very important for any reconstruction work, and Turkish companies will benefit greatly from these efforts. However, Turkey's perception of what stability in Syria means may not match the reality of the United States. The Kurdish issue in Syria opposed to the Syrian Kurdish self-rule is closely related to the Turkish Kurdish issue itself. Kurdish clans and tribes overlap on the Turkish-Syrian border, which implies close family ties and a sense of unity between the ethnic groups. With the opening of borders in recent years, this relationship has developed rapidly. In addition, given the developments in the region, the future of the Syrian Kurds has a direct impact on Turkey's stability (Tashjian 2012).

When Turkey supported the expulsion of Bashar Al-Assad (Bashar Al-Assad) in the second half of 2011, it seemed that these considerations were not fully taken into account. Indeed, Turkish leaders may have seen Syria in the recent Libya incident, and like many Western observers, they have full expectations of Syria. The Assad regime quickly collapsed. On 
the contrary, Turkey is being retaliated by the Assad regime, and the Assad regime has restored support for the PKK together with Iran. However, such claims are still difficult to prove.

These developments seem to aggravate the government's sense of panic about the Kurdish issue. Together with President Erdogan's ambitions, these developments may have accelerated his decision to reinitiate talks with the imprisoned PKK leader Abdullah Okara while attacking the PKK positions in southeastern Turkey. At the same time, at least in November 2012, after the Syrian rebels took over, Jabhat al-Nusra attacked the Kurdish Democracy near the town of Ras Al-Ain across the Turkish border. At the PYD checkpoint, the Turkish leader took at least another approach. city. This sparked a battle, killing more than 30 people (Lister 2016).

This policy may seem contradictory. But, follows a certain logic that is the Turkish army exerts pressure on the PKK in an attempt to cause damage, that is, there is PYD in northern Syria, and at the same time opens the door for a political settlement of the Turkish Kurdish problem. Overall, this policy has the opportunity to produce the expected results. However, this also brings huge risks and shows that Turkey and the United States have incompletely compatible interests on the Kurdish issue. The issue of Kurdish autonomy is especially true: From the perspective of the United States, the Kurdish Autonomous Region may become an important fortress for resisting the more hostile forces in Damascus, Syria after Assad, and the Turkish view even mentions that autonomy is a red line. This may change with the evolution of the Turkish Kurdish issue itself, but it is still Turkey's established position. An open dialogue between Ankara and PYD no longer seems impossible, and both parties have shown the same thing.

Turkey and the PKK strengthened negotiations in March 2013. The leader of the PKK, Öcalan, announced the end of the armed struggle and urged his fighters to leave Turkey. However, it remains to be seen whether Turkish leaders will retaliate by partially accepting Kurdish demands, especially regarding the deletion of references to Turkey in the constitution, allowing Kurds to receive school education, and the de facto autonomy requirement. Although it seems that a milestone has been 
reached to end this 29-year-old conflict, whether this effort will succeed is still an open question.

This process will require greater discipline and wisdom than in 2009. The "opening of the Kurds" has previously proved to be short-lived because Ankara failed to manage the process and the PKK tried to turn it into a huge propaganda head. Since Erdoğan's priority is to hold the presidency under the government's presidential system, the policy on Kurdish issues may once again become a risk of election considerations. The PKK is not a reliable partner because the organization seems to be divided on the merits of negotiations with Ankara, and the militants in Iraq are not completely controlled by Okara. Although there are reasons to be cautiously optimistic, the remaining obstacles to the road to peace should not be underestimated. Sectarian relations and power struggles in Syria. What stands out in US-Turkish relations is how to deal with the notorious Syrian opposition. In short, Turkey attaches great importance to promoting the role of the Muslim Brotherhood in the Syrian opposition, while the United States has always advocated broad-based and inclusive leadership (Harris 1980).

AKP has a strong connection with Ikhwanul. The latter is derived from the traditional Turkish Islamic movement, the "Milli Görus", and is heavily influenced by the Brotherhood. When the AKP moved to the center and coexisted peacefully with secularism, its core leadership continued to consist of individuals with a background in the MilliGörus movement. Therefore, it is not surprising that Erdoğan and Davutoğlu are passionate about the rise of the Muslim Brotherhood as a major political force after the Arab rebellion. The AKP government has been in contact with the Palestinian faction of Hamas, the Muslim Brotherhood, and expressed preference for Egyptian President Mubarak at the beginning of the demonstration. After Mohammed Morsi came to power, Ankara moved quickly to establish a strategic partnership with Egypt (Sari 2018). Also in Syria, once the Muslim Brotherhood takes weapon action against the Assad regime, the policy of the AKP government will quickly change. When there was an opportunity to support the establishment of a Brotherhood-led government in the Eastern Mediterranean, Erdogan was eager to support this prospect (Elmuendo 2011). 
This change in Turkish foreign policy is partly pragmatic and partly ideological. The pressure of the people made it necessary to stand with Arab residents, which in turn brought conflict between Ankara and Tehran. In this way, the recent political turmoil in the region and the rise of the Brotherhood (and the parties it inspired, such as Ennakhda in Tunisia), have led the Justice and Development Party to identify with the Brotherhood.

In fact, Erdogan's policies reflect most people's understanding of democracy, rather than a free constitution based on checks and balances. Therefore, in the Middle East, the leaders of the Justice and Development Party believe that the Sunni Arab majority embodies the universality of the people, while the latter is represented and led by the Brotherhood. As a result, Turkey's policy has hardly paid attention to the concerns and interests of the country's non-Sunni Arab communities, whether they are Alawites, Christians, Kurds, Druze or Syrian urban secular organizations, or Egyptian science. special. These groups also did not oppose Assad, causing them to directly conflict with Turkey's top priority in Syria. After the fall of Assad, Turkey's policy towards this group may change. Given that the Muslim Brotherhood's initial influence on Syrian politics is limited, the probability of the success of this policy is uncertain (Bozdaglioglu 2003).

Turkey is determined to balance its global hopes and regional goals, while pointing out the collapse of the Assad regime and relying on its strength on the Arab road to ensure rapid results. Prior to this, Ankara had a good relationship with the regime and carried out constitutional reforms. However, Ankara did not take into account the Syrian regime's experience in opposing dissident activities or even armed resistance. In fact, Prime Minister Erdogan has even entered a turbulent fourth month, but he still expects that "Assad will fall in a few months", and he has revised his prediction to be at the end of the first year of demonstrations. $1 / 2$ to 2 years. In addition, Ankara's call for Damascus to "put down guns, meet people's demands and resign" has become a simple call for early elections.

The strategic depth policy is the foundation of Turkey's policy. Ahmet Davutoğlu's "strategic depth" doctrine confirms that Turkey has 
become a key player. By leveraging its geopolitical and geostrategic position, Turkey hopes to become a regional and global player. As part of this vision, the Ankara government is determined to implement policies to end long-term hostilities with neighboring countries, especially in the Middle East that was once ruled by the Ottoman Empire. In 2001, Davutoğlu expressed his strategic thinking in a book called "Strategic Depth" or "Strategic Depth". He is a designer for dialogue with all political figures in the Middle East (Grigoriadis 2010).

The new doctrine of promoting regional environment has changed Turkey's views on four main issues, namely: First, Turkey accepts its status as a candidate for the EU. Second, Turkey will play a catalytic role in the relationship between the Middle East and the West. Third, Turkey clearly sees the importance of establishing closer ties with Russia. Moscow is a very important regional actor in Ankara and vice versa. The fourth is that at least eight former Soviet Union countries have ethnic and linguistic ties with Turkey. It is expected that there will be room for Turkish influence in Central Asia in the future. Nevertheless, Russia and Iran also have common interests in the Caucasus.

From the perspective of strategic depth, in addition to maintaining relations with the West, Turkey also attaches special importance to East Timor. Given that this view is based on historical and geo-strategic stance, Turkey views improving Asian relations and expanding its influence in the region as a strategy to increase its influence in Europe. One of the key points of the strategic depth principle is the idea of minimizing or completely eliminating neighbor problems (zero problems in neighbor policies). According to Davao Tolu, Turkey's strategic interests lie in peace, stability, security and prosperity in the region and beyond. (Grigoriadis 2010).

When the Syrian crisis broke out, Turkey's foreign policy doctrine that gave priority to the region also promoted Turkish policy. In this case, Turkey is facing the threat of the spread of the Syrian conflict, so it has aroused great attention to the conflict. It can be concluded that the Syrian conflict is a threat to Turkey's national interests. In addition to the Syrian conflict, this also poses a threat to Turkish foreign doctrine. The role of the strategic depth doctrine concerning Turkey's geographic region is 
threatened because the doctrine is soft power and emphasizes economic development and planning policies (Grigoriadis, 2010).

Analyzing Turkey's foreign policy doctrine from the perspective of John Agnew's critical geopolitical theory, it can be seen that due to the geographical relationship between the two countries, Turkey and Syria have always been prone to conflicts in history, but they It also has considerable economic potential. country. In this regard, John Agnew put forward several points including the existence of agents and agents. In this case, the agent is the main body of the participant who determines the way of interaction, and the agent is The parties to the conflict in the crisis are the opposition and the Syrian government, and agency is an inherent problem. In this case, the conflict is an Arab spring wave (Fahham 2016).

In addition to this, it is also possible to perform mapping related to the perception of the location, in this case, it is related to potential problems in the area. As far as the sense of place is concerned, it means that Syria may become a strategic region in the political and political landscape. In terms of the geography of Syrian territory, Syrian territory is a strategic area of Russian defense. In the case of Bashar al Bashar alAssad as an actor, he also plays an important role, especially the historical connection between Russia and Syria. The intimacy in history occurred during the Cold War, and the future of Russia is still like the emergence of the alliance and the Syrian Arab socialist and pan-Arab movements (Pranissa 2014).

Turkey directly borders Syria and its territory is under threat. The theory describes a situation where existing threats can spread more easily at short and long distances. Therefore, security in the area depends on each other, which makes security more complicated. This leads to an increase in the relationship between the actors involved, either directly within the complexity or outside the existing complexity of security.

From the perspective of the security complex, this situation not only comes from border issues, but also from Syrian refugees. As we all know, Turkey has hosted about 300,000 Syrian refugees. In addition, Turkey is strengthening its economic strength. The experience of a 
military coup in Turkey also made the Turkish government under the AKP fear, because several military coups in Turkey were caused by Turkey's decline and economic crisis. In addition, Turkey has also established good relations with Russia and NATO (Barrinha 2014). Therefore, Turkey's foreign policy currently has no clear goals. If Turkey's policy prior to the Syrian crisis maintained regional cooperation in the presence of the Levantine Quartet, which is an alternative to the European Union's decision not to authorize Turkey to become a permanent member of the European Union, then when the crisis occurs, Turkey will face I have to reposition myself to the European Union and feel confused.

Turkey's foreign policy is greatly affected by the external environment related to the Syrian crisis, Russia, the European Union and NATO as the source of Turkish foreign policy. In this case, Turkey has shown a response to the Syrian crisis. The Syrian crisis threatens security, and the rebels or the opposition are the social roots affecting border security policies. In addition, the Turkish Parliament, which responded to the border incident, is the government's source of information. Among the sources, Erdoğan and Ahmet Davutoğlu hold this position. In this case, Erdoğan served as Turkish Prime Minister, responded to the repressive actions and served the interests of Turkish partners in the Syrian crisis, and Ahmet Davutoğlu's role More is the implementation of Turkey's foreign policy doctrine, that is, the normalization policy of strategic views. In this regard, the priority list is a consideration for Ahmet Davutoğlu, as well as a consideration for maintaining NATO's status and relations with the EU (Tashjian 2012).

\section{Conclusion}

Since the Justice and Development Party came to power, Turkey used to maintain good relations with the Bashar al-Assad government, but Turkey suddenly requested the resignation of President Bashar alAssad. The reason for the Turkish government is that the Bashar al-Assad government is an undemocratic regime and a regime that violates human rights. A few months after the establishment of the Syrian Liberation Forces and the civil war, the Turkish government supported the establishment of the Syrian National Assembly in Istanbul. After at least five Turkish citizens were killed in the incident on the Turkish-Syrian 
border, the Turkish government improved border security by lowering tanks and fully equipped military equipment. Turkey also asked some NATO members to provide assistance to protect the border between Turkey and Syria. In addition to some of these policies, Turkey also provides assistance to Syrian rebels.

From the perspective of defense management, the call for Assad to resign is based on preventing Syrian refugees from going to Turkey. The aim is to maintain Turkey's social and economic stability, which may be shaken by the existence of these refugee groups. In addition, the economic aspect that is in Turkey's interests, namely Syria, is a key area that has become the foundation of Turkey's economic growth. Considering that Turkey is a neighboring country of Syria, the deep conflict in Syria may also pose a huge threat to Turkey. Therefore, Turkey must inevitably be involved in the conflict.

Turkey's policy of supporting and providing weapons assistance to the Syrian rebels is considered a form of preventing the spread of the Syrian conflict. People worry that the spread of the Syrian conflict will affect Turkey's security and stability. Some parties also believe that this step is risky. This risk has arisen due to the Kurdistan problem. The emphasis on geopolitics has become an analysis tool for Turkey's policies related to the Syrian crisis.

Turkey's foreign policy doctrine is a strategic monograph, emphasizing geopolitical and historical aspects. This doctrine is the result of Ahmet Davutoğlu's research and performance, and clarifies the region's participation in Turkish foreign policy. Deph's strategic theory has the following points, namely, security and freedom balance as the principle of proposing Turkish security as a balanced concept of global security, zero problems with neighboring countries encourage Turkey to improve relations with neighboring countries, involving common security and economic integration Coexistence, political cooperation, high regional visibility. In addition to being a NATO member and Turkey's desire to become a full member of the European Union, this is also one of the factors. In this case, the European Union declared its opposition to the resignation of Syrian President Bashar Bashar al-Assad. In addition, Turkey's steps as a pioneer in resolving conflicts have also become a 
bargaining position as a full member of the European Union, which emphasizes the principles of democracy and human rights.

\section{References}

Akbar, Aulia. Oke Zone. 25 Mei 2011. https://news.okezone.com/read/2011/05/25/412/460741/akti vis-ham-desak-resolusi-pbb-atas-suriah (diakses Juli 30, 2020).

Alessandri, Emiliano. "The New Turkish Foreign Policy and the Future of Turkey-EU Relations." Istituto Affari Internazionali, 2010.

Aljazeera. 26 Maret 2011.

http://www.aljazeera.com/news/middleeast/2011/03/2011325 145817688433.html (diakses 7 30, 2020).

Amin, A. Miftahul. "Pengaruh Adalet ve Kalkinma Partisi (AKP) dalam Transformasi Peta Politik di Turki." Jurnal Agama dan Hak Azazi Manusia Vol. 4, No. 1, 2014.

Barrinha, Andre'. "The Ambitious Insulator: Revisiting Turkey's Position in Regional Security Complex Theory." Mediterranean Politics, Vol. $19,2014$.

BBC Indonesia. 13 Juni 2013.

http://www.bbc.com/indonesia/dunia/2013/06/130613_suriah _pbb_korban_konflik (diakses 07 30, 2020).

BBC News. 16 Maret 2016. http://www.bbc.com/news/world-middleeast-26116868 (diakses 7 30, 2020).

$B B C$ News. 8 Juni 2015. http://www.bbc.com/news/world-europe33043812 (diakses 7 30, 2020).

Bozdaglioglu, Yücel B. Turkish Foreign Policy and Turkish Identity a Constructivist Approach. New York \& London: Routledge, 2003.

Buzan, Barry. People, States and Fear. Lynne Rienner Pub, 1991.

Cresswell, John W. Research Design: Pendekatan Metode Kualitatif, Kuantitatif, dan Campuran. 4. Yogyakarta: Pustaka Pelajar, 2016.

Daoudy, Marwa. "The structure-identity nexus: Syria and Turkey's collapse (2011)." Cambridge Review of International Affairs Vol. 29, 
2016.

Dinc, Cengiz. "Transformation of Turkish Foreign Policy Toward the Middle East : From Non-Involvement to a Leading Role ." ALTERNATIVES TURKISH JOURNAL OF INTERNATIONAL RELATIONS, t.thn.

Elmuendo, Ana. "Ner Turkish Foreign Policy Towards Middle East ." European Institue of The Mediterranean Vol. 4, 2011.

Fahham, A. Muchaddam. "Konflik Suriah: Akar Masalah dan Dampaknya." Jurnal DPR RI, 2016.

Feffer, John. HUFFPOST. t.thn. https://www.huffpost.com/topic/turkeyakp-party (diakses Juli 30, 2020).

Grigoriadis, Ioannis N. "The Davutoğlu Doctrine and Turkish Foreign Policy." Hellenic Foundation for European and Foreign Policy (ELIAMEP) Working Paper No. 8, April 2010.

Hari Bucur-Marcu, Philipp Fluri, and Todor Tagarev. Defence Management: An Introduction. Jenewa: Geneva Centre for The Democratic Control of Armed Forces (DECAF), 2009.

Harris, George S. The government politics of Middle East and North Africa. Boulder Colorado: Westview press, 1980.

Imai, Kohei. "Rethinking the Insulator State: Turkey's Border Security and the Syrian Civil War." Eurasia Border Review Vol. 7, No. 1, 2016.

Kamrullah, Muhammad Rizky Nur. "Jabhat Al-Nusra sebagai Aktor Kekerasan Non-Negar Penting dalam Konflik Bersentaja di Suriah." Global: Jurnal Politik Internasional Vol. 19, No. 2, 2017.

Lister, Charles. "Profiling Jabhat Al-Nusra." The Brookings Project on U.S. Relations with the Islamic World, Analysis Paper, Juli 2016.

Muhammad, Mahadhir. "Kebijakan Politik Pemerintahan Bashar Al-Assad di Suriah." Jurnal Agama dan Hak Azazi Manusia Vol. 6, No. 1, 2016.

Navari, Cornelia. China - US Focus. 12 September 2016. (diakses Agustus $5,2020)$.

Pranissa, Nikita. Aktor Besar dalam Konflik Suriah. Skripsi, Depok: 
Universitas Indonesia, 2014.

Rendra, Dwi Suta Mentari. "Keterlibatan Turki dalam Konflik Suriah Pada Tahun 2011-2012." Jurnal Analisis Hubungan Internasional Vol. 6, No. 2, 2017.

Saputra, Miftahul Ghani. "Keterlibatan Rusia dalam Perang Sipil Suriah Tahun 2011-2016." Jurnal Analisis Hubungan Internasional Vol. 7, No. 3, 2018.

Sari, Renita Purnama. "Pemutusan Hubungan Diplomatik Turki dan Mesir Tahun 2013.” eJournal Ilmu Hubungan Internasional Vol. 6, No. 3, 2018.

Supriyatno, Makmur. Pengantar Manajemen Pertahanan. Bogor: Universitas Pertahanan, 2018.

-. Tentang Ilmu Pertahanan. Jakarta: Yayasan Pustaka Obor Indonesia, 2014.

Syukran. "Dampak Kebijakan Pintu Terbuka (Open Door Policy) Turki bagi Pengungsi Ssuriah Terhadap Kepentingan Nasional Turki Tahun 2011 - 2016." Jurnal Ilmiah Mahasiswa FISIP Unsyiah Vol. 4, No. 4, 2019.

Tashjian, Yeghig. "From Conceptualization to Implementation and Revaluation: Turkey's "Strategic Depth" in the MENA region." Strategic Outlook, 2012.

Tezcür, Güneş Murat. "Kurdish Nationalism and Identity in." European Journal of Turkish, 2009.

Tocci, Nathalie. "Turkey and the European Union: A Journey in the Unknown." Turkey Project Policy Paper No. 5, November 2014.

Zurcher, Erick J. Turkey: A Modern History. Leiden: I.B. Tauris, 2003. 